\title{
Porównanie możliwości diagnostycznych metod magnetycznej pamięci metalu, szumu Barkhausena i niskoczęstotliwościowej impedancji
}

\author{
Comparison of diagnostic capabilities \\ of metal magnetic memory method, Barkhausen noise method \\ and low-frequency impedance spectroscopy method
}

\section{Streszczenie}

W artykule przedstawiono trzy metody badań nieniszczących: metodę magnetycznej pamięci metalu, szumu Barkhausena i niskoczęstotliwościowej impedancji. Zwrócono uwagę na niejawny, nieliniowy związek istniejący pomiędzy parametrami mechanicznymi i elektromagnetycznymi materiału, a stanem jego wytężenia i degradacji. Omawianą tematykę zobrazowano przykładami, na podstawie których wykazano celowość uwzględnienia charakterystyk częstotliwościowych parametrów elektromagnetycznych materiału w opisie symptomów diagnostycznych metody magnetycznej pamięci metalu i szumu Barkhausena.

Słowa kluczowe: przewodnik; mikrostruktura; przenikalność magnetyczna; konduktywność; degradacja materiału; NDT; SHM

\section{Abstract}

This paper presents three NDT method: Magnetic Metal Memory Method, Barkhausen noise method and LFIS method. The attention has been drawn to the implicit and non-linear relationship that exists between the mechanical and electromagnetic parameters of the material and the degree of effort and degradation of the structure. Presented topic has been illustrated by examples, on the basis of which demonstrated purposefulness of taking in the account frequency characteristics of electromagnetic parameters of the material in the describtion of diagnostic symptoms of Metal Magnetic Memory method and Barkhausen noise.

Keywords: conductor; microstructure; permeability; conductivity; material degradation; NDT; SHM

\section{Wstęp}

Trzy metody badań nieniszczących: magnetyczna pamięć metalu (MPM), szum Barkhausena (BN) i niskoczęstotliwościowa spektroskopia impedancji (LFIS) umożliwiają identyfikację stanu technicznego przewodnika materiału przewodzącego prąd elektryczny (przewodnika) i jego wytężenia [ $1 \div 6]$. Różnice między ww. metodami dotyczą:

- celu i zakresu badań,

- typu badanego materiału,

- metody magnesowania materiału,

- pasma częstotliwości mierzonego sygnału,

- algorytmów analizy danych i symptomów diagnostycznych. Wspólnym obszarem opisywanych metod są właściwości elektryczne i magnetyczne badanego materiału, które są odwzorowane niejawnie w symptomach diagnostycznych. Każda z ww. metod może zwiększyć swoje możliwości funk- cjonalne i prawdopodobieństwo poprawnej diagnozy (POD), gdy w algorytmach analizy danych pomiarowych i kryteriach diagnostycznych uwzględni wiedzę pozyskaną przez pozostałe dwie metody - efekt synergii. Wiedza diagnosty musi być również powiązana z wiedzą specjalisty inżynierii materiałowej w zakresie charakterystyk opisujących główne

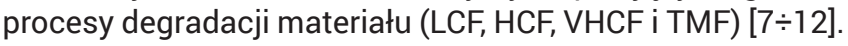

\section{Charakterystyka metod badawczych}

Metoda MPM jest przykładem procesu analizy sygnału pozyskanego z obiektu typu „czarna skrzynka”, o nieznanych wymuszeniach i właściwościach (rys. 1). Zagadnienie podobne do diagnostyki wibroakustycznej. W tej metodzie

Dr hab. inż. Maciej Roskosz - Politechnika Śląśka; dr inż. Mirosław Witoś - Instytut Techniczny Wojsk Lotniczych; dr hab. inż. Zbigniew Hilary Żurek, prof. nzw. PŚl.; mgr inż. Krzysztof Fryczowski - Politechnika Śląśka.

Autor korespondencyjny/Corresponding author. maciej.roskosz@polsl.pl 
diagnosta rejestruje i analizuje informację o zastanym namagnesowaniu materiału, która jest nieliniowo skorelowana z mikrostrukturą, historią eksploatacji, poziomem degradacji, gęstością dyslokacji i tarciem wewnętrznym [13]. Pozostałe dwie metody są przykładem procesu analizy systemu o nieznanych cechach i sygnałach sterujących, identyfikowanego na bazie odpowiedzi badanego obiektu na znany sygnał wymuszający (rys. 1). W obu aktywnych metodach NDT diagnosta lokalnie przemagnesowuje materiał w celu uzyskania podstawowej informacji o badanym materiale, kasując przy okazji częściowo lub całkowicie informację zapisaną w materiale przez efekty magneto-mechaniczne o historii eksploatacji obiektu.

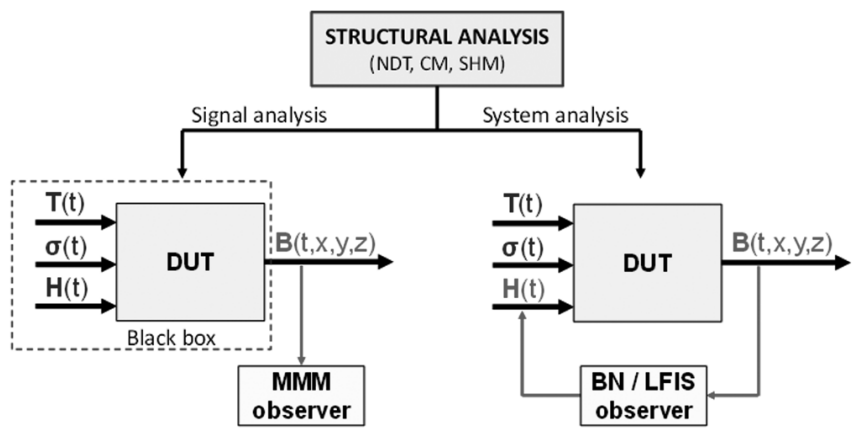

Rys. 1. Diagnozowanie obiektu badań (DUT) metodami elektromagnetycznymi: a) metoda MPM - proces analizy sygnału; b) metoda BN i LFIS - proces analizy systemu $(T(t)$ - temperatura, $\alpha(t)$ - naprężenia mechaniczne i termiczne, $H(t)$ - natężenie zewnętrznego pola magnetycznego, $\mathrm{B}(t)$ - indukcja magnetyczna w punkcie pomiarowym)

Fig. 1. Diagnosing device under testing (DUT) by electromagnetic methods: a) MMM method - a process of signal analysis; b) BN and LFIS methods - a process of system analysis $(T(t)$ - temperature, $\alpha(t)$ - mechanical and thermal stresses, $\mathrm{H}(t)$ - the intensity of an external magnetic field, $\mathrm{B}(t)$ - magnetic induction at the measurement point) skorelowane ze stanem naprężeń I, II i III rodzaju, niejednorodnością składu chemicznego i struktury (m.in. gęstości dyslokacji, strefą HAZ spoiny) oraz defektami struktury $[6,10,15,16]$. Metoda MPM umożliwia (rys. 3):

- szybką lokalizację obszarów materiału o odmiennych właściwościach magnetycznych i elektrycznych („stref koncentracji naprężeń" wg Dubova [11,12]);

- diagnozowanie wczesnej fazy degradacji zmęczeniowej materiału, poprzedzającej otwarte pęknięcie, pod warunkiem zachowania staranności metrologicznej i używania wiarygodnych algorytmów analizy danych pomiarowych $[1,14]$.

$\mathrm{Na}$ podstawie analizy SWOT i badań własnych wyznaczono mocne i słabe strony metody MPM [14]. Stwierdzono m.in., że:

- Mocną stroną metody MPM są efekty magnetomechaniczne, znane i opisane $\mathrm{w}$ literaturze od ponad 150 lat oraz wyniki badań magnesowania naprężeniowego ferromagnetyków w słabym polu magnetycznym wykonane $w$ różnych ośrodkach naukowych na świecie $[1,16 \div 20]$.

- PN ISO 24497:1-3 może być stosowana tylko do diagnozowania spoin spawalniczych nieruchomych obiektów, np. rurociągów i kadłubów maszyn stacjonarnych.

- W normie PN ISO 24497:1-3 istnieją błędy logiczne, które obniżają POD diagnozy MPM, m.in. w algorytmie i kryteriach diagnostycznych pominięto właściwości elektryczne i magnetyczne materiału!

- Wszystkie słabe strony metody MPM i jej aplikacji (produktów firmy Energodiagnostyka) mogą być usunięte przy obecnym poziomie techniczno-technologicznym i badawczym, np. wykorzystując dostępną komercyjnie kamerę magnetyczną Mageye firmy Matesy o polu roboczym 8x8 mm dzięki której można uzyskać rozkład powierzchniowy składowej namagnesowania materiału w postaci magnetogramów.

\section{Metoda magnetycznej pamięci metalu}

Metoda magnetycznej pamięci metalu jest stosowana do diagnozowania materiałów ferro-magnetycznych i metastabilnych materiałów paramagnetycznych [14]. Podczas badań MPM rejestrowane i analizowane są:

- zastany rozkład składowej stałej namagnesowania materiału (namagnesowanie resztkowe dla konstrukcji odciążonej, namagnesowanie naprężeniowe dla konstrukcji obciążonej, ślady magnetyczne pozostawione po defektoskopii MT lub robotach do defektoskopii UT i RT);

- lokalne anomalie magnetyczne (odstępstwo od trendu, uwzględniające kształt badanego obiektu i jego położenie względem ziemskiego pola magnetycznego).

Magnesowanie materiału i faza zapisu informacji diagnostycznej jest realizowana przez zewnętrzne pole magnetyczne, naprężenia mechaniczne i termiczne, zmiany temperatury materiału oraz procesy degradacji struktury zmieniające poziom rozpraszania energii wewnętrznej oraz parametry elektryczne i magnetyczne materiału (rys. 2). Procesy na które w metodzie MPM diagnosta nie ma wpływu, ale których wypadkowe skutki może wiarygodnie zmierzyć przy pomocy taniego magnetometru.

Prawdziwe symptomy diagnostyczne MPM (po wykluczeniu fałszywych anomalii magnetycznych z danych pomiarowych) mogą być
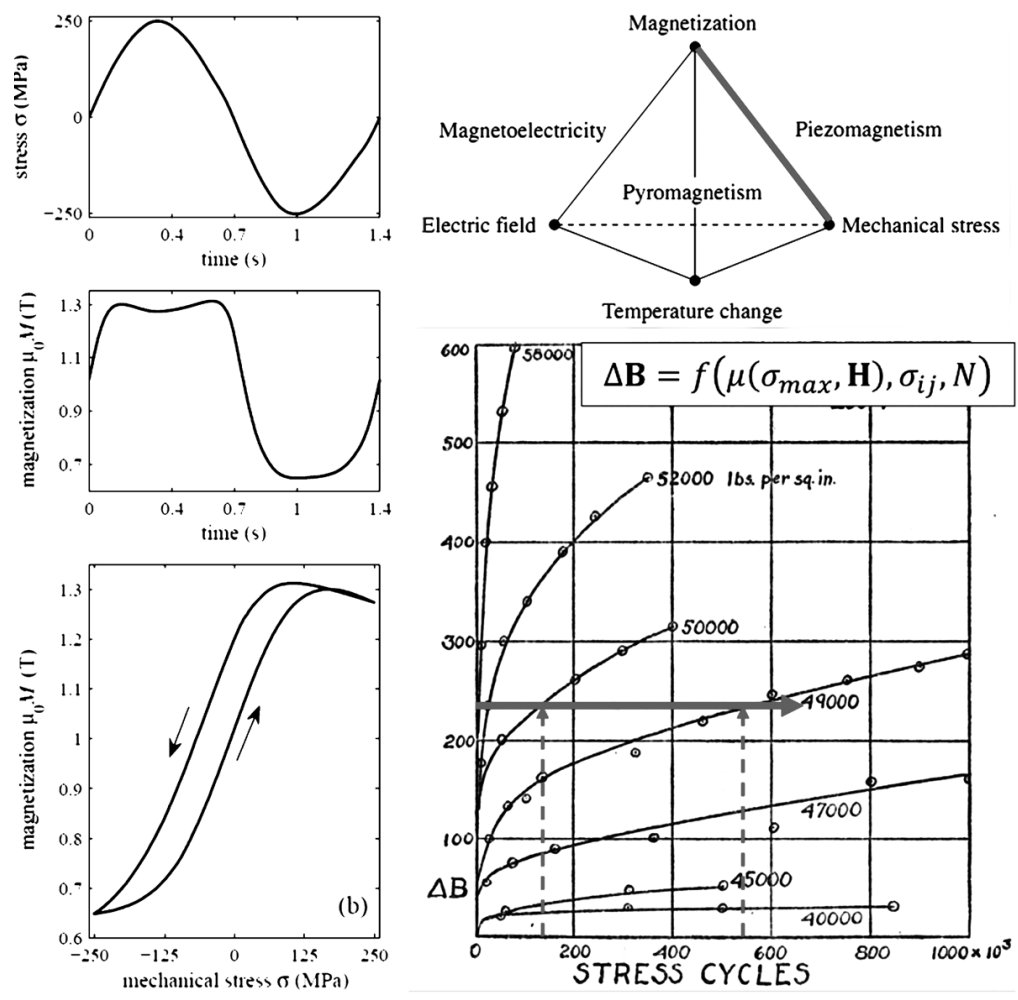

Rys. 2. Zobrazowano podstawy teoretyczne metody MPM - magnesowanie naprężeniowe i zmianę namagnesowania resztkowego ferromagnetyka pod wpływem cyklicznego naprężenia mechanicznego i rozpraszania energii w materiale $[14,17]$ Fig. 2. Ilustration of the theoretical basis of the MMM method -magnetization caused by stress and a change of residual magnetization of ferromagnetic material influenced by cyclic loading and energy dissipation in the material $[14,17]$ 

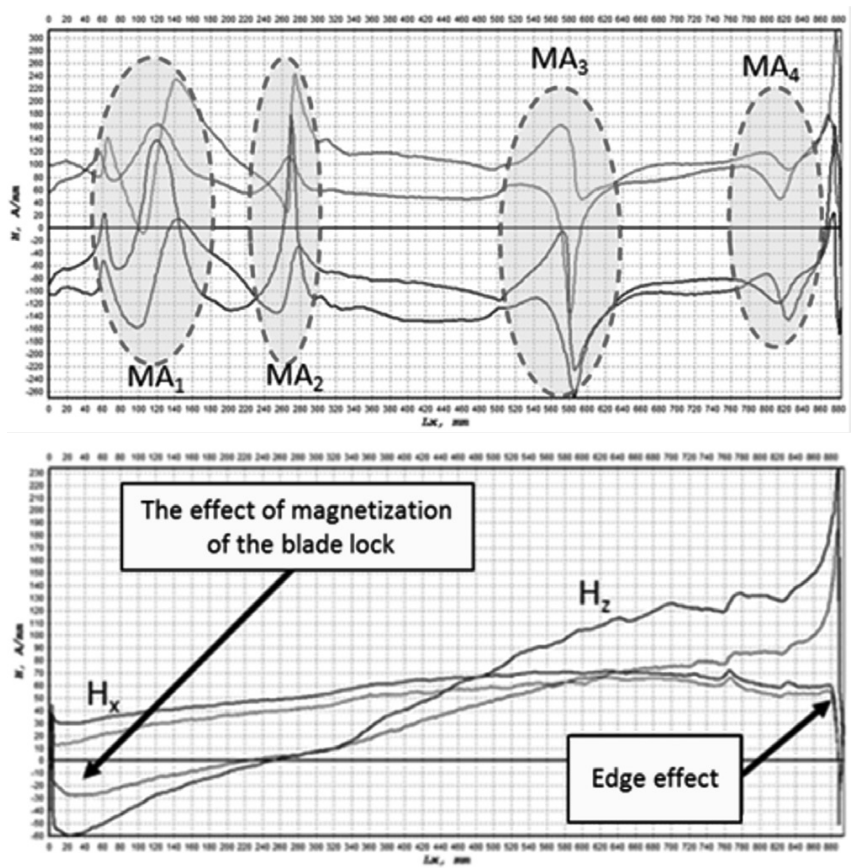

Rys. 3. Wykorzystanie efektu MPM ferromagnetyka do diagnozowania ukrytego, szerokopasmowego przeciążenia łopatki ND-37 części niskoprężnej turbiny parowej: a) magnetogram przeciążonej łopatki w fazie poprzedzającej pęknięcie (MA - strefa anomalii magnetycznej skorelowana $z$ linią węzłową drgań); b) magnetogram łopatki nie przeciążonej (referencyjny) [14]

Fig. 3. MMM effect application for diagnosis of the hidden wideband overload of the LP steam turbine ND-37 blade: a) magnetogram of overloaded blade in the pre-crack phase (MA - magnetic anommaly zone correlated with nodal line of the vibration), b) magnetogram of the reference blade [14]

\section{Metoda szumu Barkhausena}

Metoda szumu Barkhausena jest stosowana tylko do diagnozowania stanu wytężenia materiałów ferromagnetycznych i jednorodności ich warstwy wierzchniej $[2,5,25]$. W badaniach rejestrowany jest sygnał stochastycznego przemieszczania się granic domen magnetycznych podczas sztucznego przemagnesowania materiału z częstotliwością od 0,1 do $120 \mathrm{~Hz}$. Sygnał krótkotrwałego, szerokopasmowego zaburzenia pola magnetycznego jest wykrywany w pobliżu badanego elementu przy pomocy cewki lub szerokopasmowego magnetometru. Ze względu na stochastyczny charakter sygnału, symptomy diagnostyczne muszą być wyznaczane jako średnia wartość z kilku cykli przemagnesowania. Są one skorelowane z siłą koercji i stratami histerezy magnetycznej materiału - parametrami umożliwiającymi ocenę ilościową i jakościową mikrostruktury ferromagnetyka, jego twardości mechanicznej i stanu wytężenia oraz stanu zaawansowania procesów zużycia. Przykładowe wyniki badań przedstawiono na rysunkach 4 i 5 .

\section{Metoda niskoczęstotliwościowej impedancji}

Metoda niskoczęstotliwościowej impedancji jest stosowana do diagnozowania wszystkich materiałów przewodzących prąd elektryczny (ferromagnetyków, paramagnetyków i diamag-netyków) [4,5]. W warunkach laboratoryjnych pomiary charakterystyk impedancji sondy oraz identyfikacja właściwości elektrycznych i magnetycznych materiału są wykonywane w paśmie od kilku $\mathrm{Hz}$ do kilku MHz (rys. 6). W badaniach NDT pomiary impedancji są wykonywane tylko na kilku wybranych częstotliwościach lub na częstotliwości rezonansowej sondy. Gdy używany jest tani, podręczny mostek LCR, to pomiary impedancji są wykonywane tylko dla 5
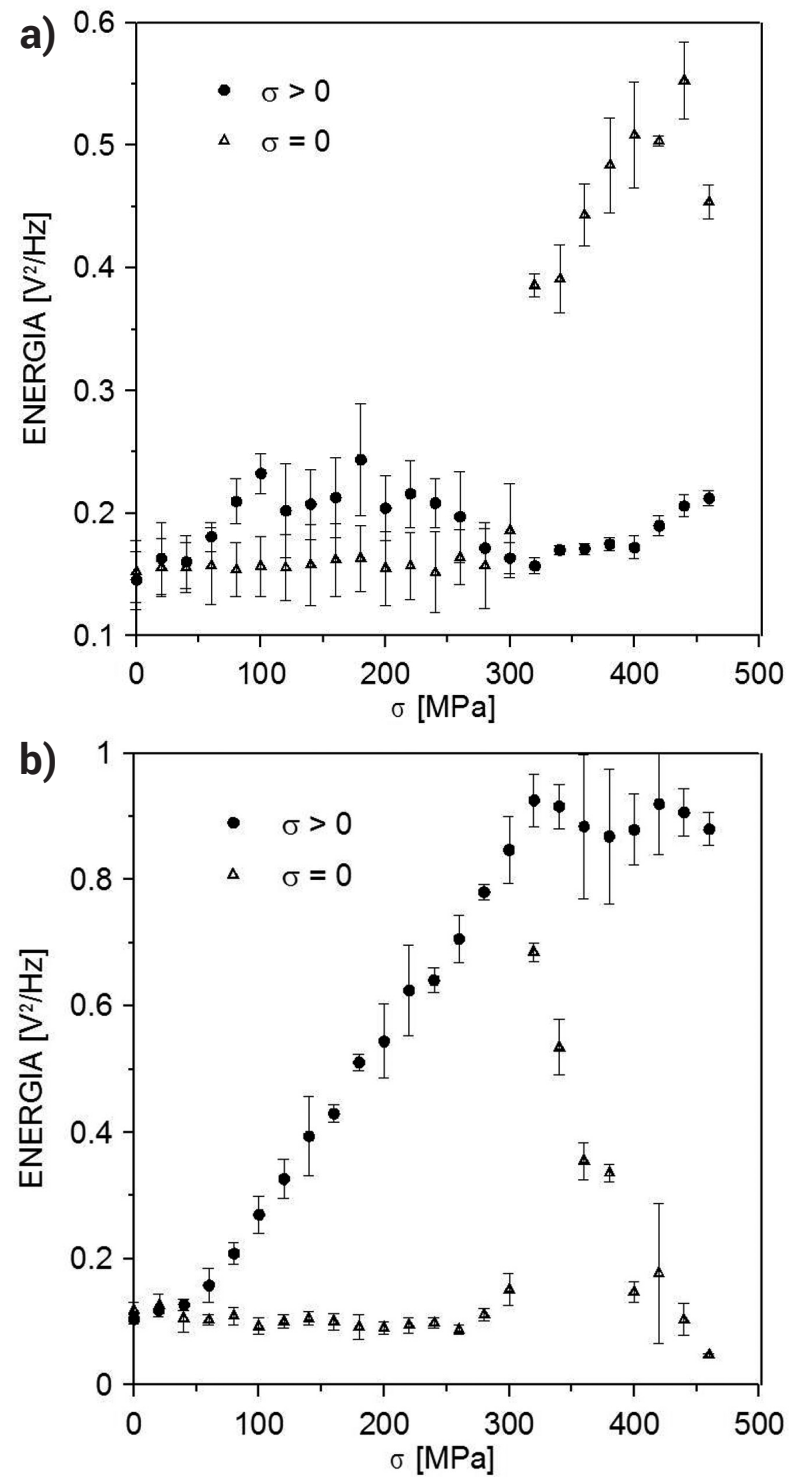

Rys. 4. Relacje pomiędzy naprężeniami a energią szumu Barkhausena [21]: a) pomiar w kierunku X - prostopadłym do kierunku obciążania, b) pomiar w kierunku Y - współosiowy z obciążeniem

Fig. 4. Relation between stress and Barkhausen noise energy [21]: a) measurement in direction $X$ - perpendicular to direction of the load, b) measurement in direction $X$ - parallel to direction of the load

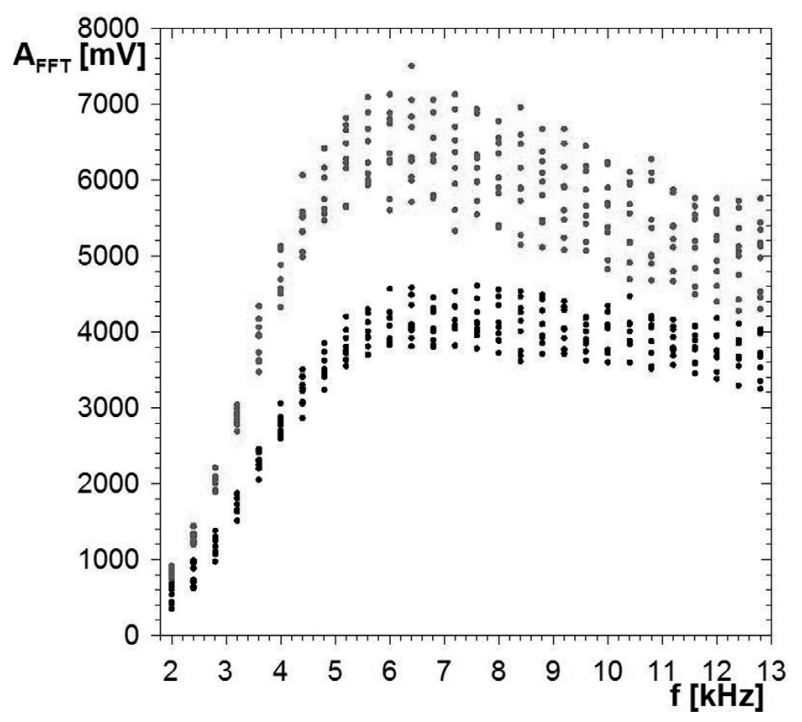

Rys. 5. Rozkład amplitudy FFT w funkcji częstotliwości (kolor czarny - stan dostawy, kolor czerwony - stan po pełzaniu) [22]

Fig. 5. FFT amplitude distribution in function of frequency (black - delivery state, red - after creep test state) [22] 
częstotliwości (100 Hz, $120 \mathrm{~Hz}, 1$ kHz, 10 kHz i 100 kHz). Podczas badań rejestrowane są równocześnie sygnały napięcia $u(\omega, t)$ i prądu elektrycznego $i(\omega, t)$ w cewce testującej, która jest magnetycznie (indukcyjnie) sprzężona z badanym materiałem. Sygnałem referencyjnym jest charakterystyka częstotliwościowa impedancji sondy bez wpływu badanego materiału $Z_{0}(\omega)$ i impedancja sondy $z$ wpływem materiału wzorcowego $Z_{\mathrm{mw}}(\omega)$. Cewka testująca z wpływem materiału paramagnetycznego jest cewką liniową, natomiast z ferromagnetykiem jest cewką nieliniową. Impedancja cewki nieliniowej jest silnie zależna od poziomu sygnału testującego (magnesującego) i charakterystyki $\mathrm{B}(\mathrm{H})$ magnesowania badanego materiału ferromagnetycznego.

Impedancja elektryczna sondy i jej składowe opisuje relacja:

$$
Z(\omega)=u(\omega, t) / i(\omega, t)=|Z| e^{-j \varphi}=R+j X
$$

gdzie $|Z|=|Z|(\omega)$ jest modułem impedancji $\left(|Z|=\sqrt{ } R^{2}+X^{2}\right)$; $\varphi=\varphi(\omega)$ jest przesunięciem fazowym między napięciem a natężeniem prądu elektrycznego; $R=R(\omega)$ jest rezystancją (oporem czynnym), która odpowiada za prąd płynący w fazie $z$ napięciem i moc czynną; $X=X(\omega)$ jest reaktancją (oporem biernym), która odpowiada za prąd przesunięty względem napięcia o $\pm 90^{\circ}$ i moc bierną; $\omega=2 \pi f$ jest częstością kołową; $j$ jest jednostką urojoną liczby zespolonej $\left(j^{2}=-1\right)$.

Impedancja sondy (cewki powietrznej) bez oddziaływania badanego materiału i pojemności toru pomiarowego jest opisana relacją:

$$
Z_{0}=R_{0}+j \omega L_{0}
$$

Impedancja cewki powietrznej z oddziaływaniem badanego materiału opisuje zależność [24]:

$$
\begin{gathered}
Z_{e q}=Z_{0}+\left(\omega^{2} M^{2}\right) /\left(R_{e}+j \omega L_{e}\right)= \\
=\left(R_{0}+\left(\omega^{2} M^{2}\right) /\left(R_{e}^{2}+\left(\omega L_{e}\right)^{2}\right) R_{e}\right)+ \\
+j \omega\left(L_{0}-\left(\omega^{2} M^{2}\right) /\left(R_{e}^{2}+\left(\omega L_{e}\right)^{2} L_{e}\right)\right.
\end{gathered}
$$

gdzie $R_{e}$ i $L_{e}$ są ekwiwalentną rezystancją i indukcyjnością pętli prądów wirowych na powierzchni badanego materiału; $M$ jest indukcyjnością wzajemną.

Parametry elektryczne i magnetyczne przewodnika:

- zespolona konduktywność elektryczna $\sigma=\sigma_{1}+j \sigma_{2}=\mathrm{J} / \mathrm{E}$, która odwzorowuje relację między gęstością prądu elektrycznego J w materiale z natężeniem pola elektrycznego E powodującego przepływ tego prądu;

- zespolona przenikalność elektryczna $\varepsilon=\varepsilon_{1}+j \varepsilon_{2}=D / E$, która charakteryzuje zdolność materiału do zmiany indukcji pola elektrycznego D przy zmianie natężenia pola elektrycznego $\mathrm{E}$;

- zespolona przenikalność magnetyczna $\mu=\mu_{1}+j \mu_{2}=\mathrm{B} / \mathrm{H}$, która określa zdolność materiału do zmiany indukcji magnetycznej B przy zmianie natężenia pola magnetycznego $\mathrm{H}$. są wyznaczane z wyników pomiarów impedancji elektrycznej sondy na podstawie obwodu zastępczego materiału (rzeczywistego induktora), modelu transformatora i dodatkowych relacji

$$
\sigma \propto R^{-1}, \varepsilon \propto C, \mu \propto L
$$

Możliwości diagnostyczne metody niskoczęstotliwościowej impedancji, wykraczające poza typowy zakres badań NDT, zobrazowano na rysunku 7.
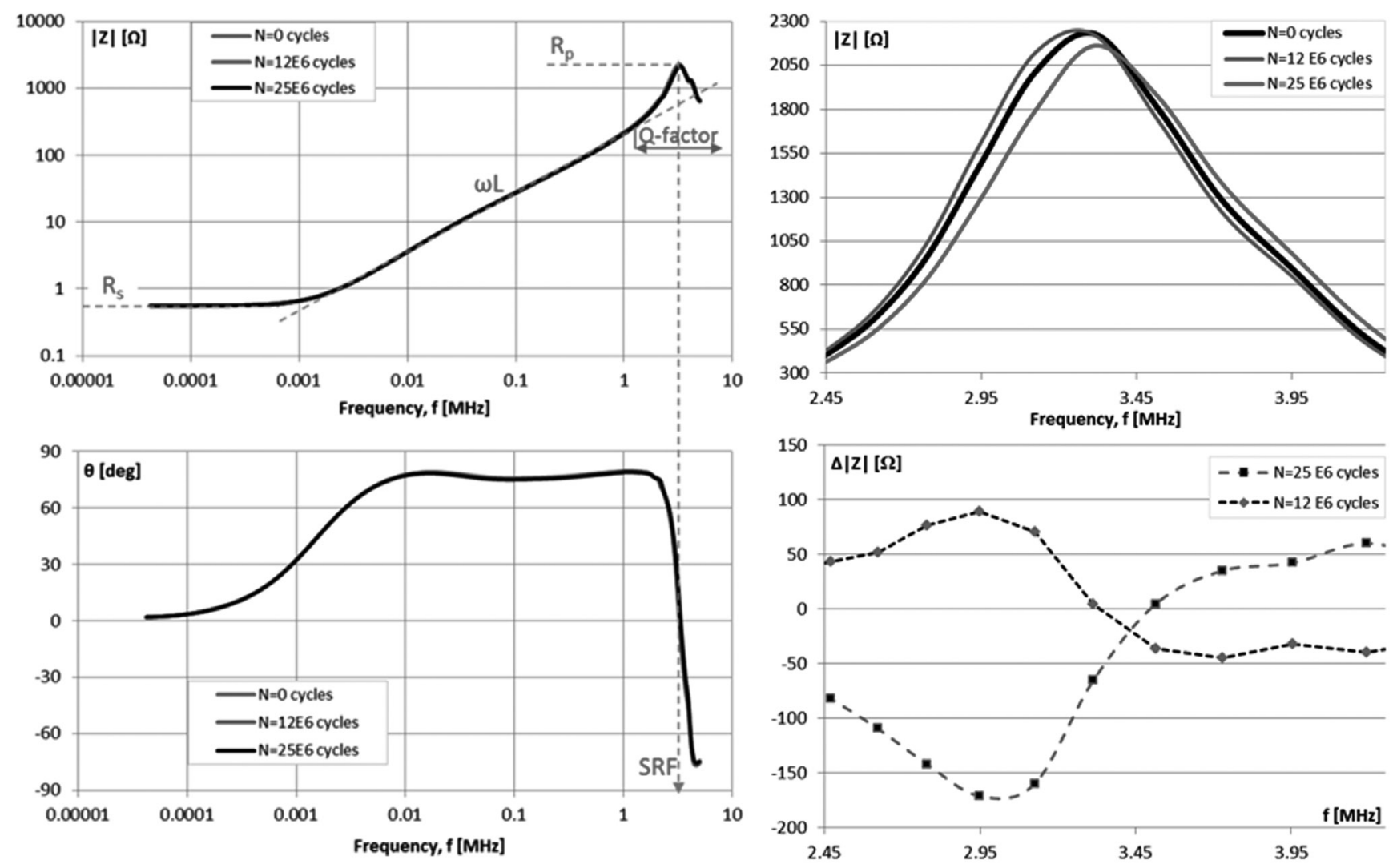

Rys. 6. Charakterystyka impedancji sondy sprzężonej z stabilną stalą austenityczną, przed i po próbie zmęczeniowej $\left(R_{p}-\right.$ impedancja obwodu równoległego LCR, SRF - częstotliwość rezonansowa sondy sprzęgniętej z materiałem)

Fig. 6. Impedance characteristics of probe inductive coupling with austenitic stainless steel before and after the fatigue test $\left(R_{p}-\right.$ impedance of parallel LCR circuit, SRF - self resonance frequency of probe coupling with the test material) 

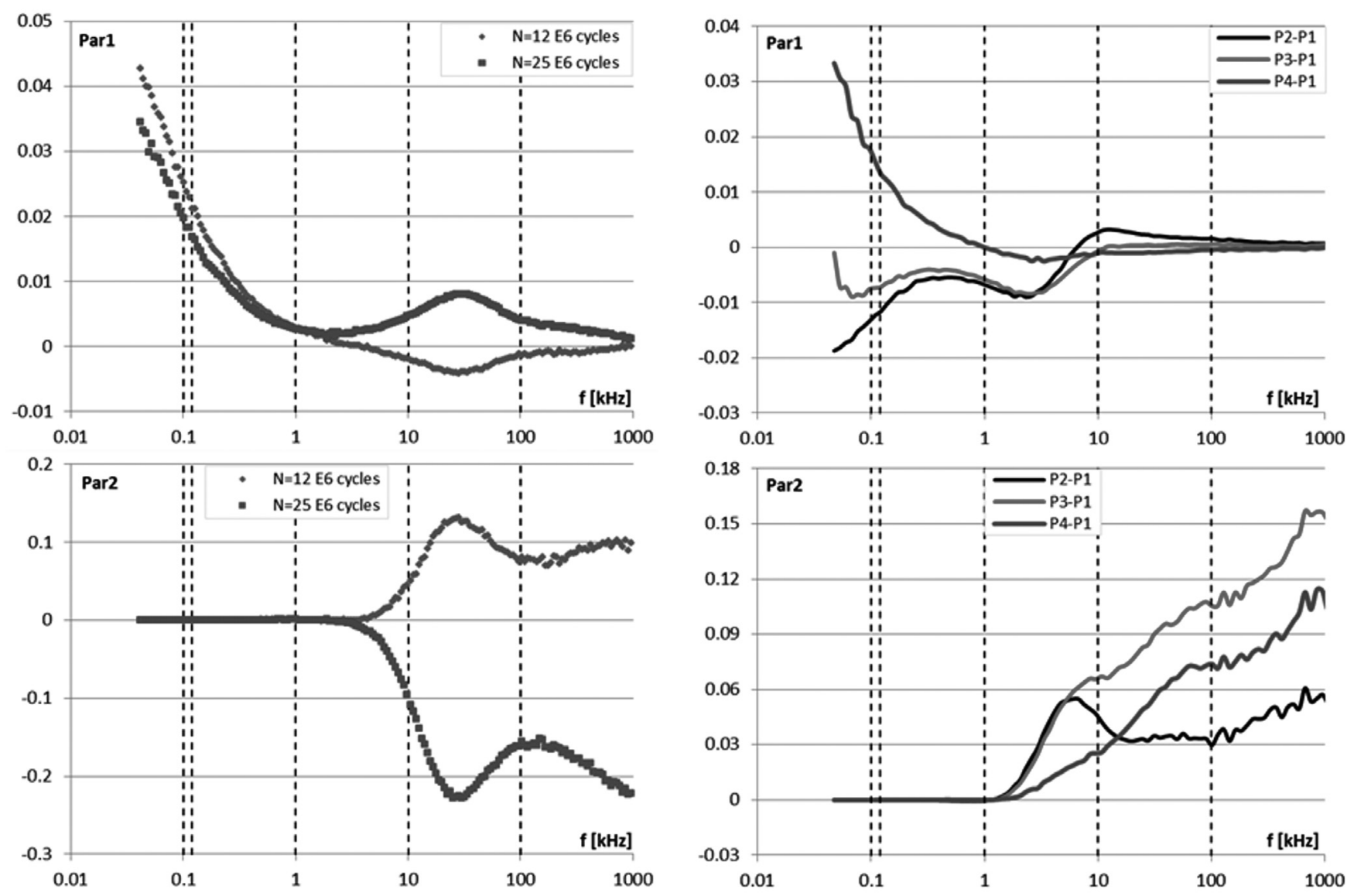

Rys. 7. Symptomy diagnostyczne (estymatory $P_{a} r_{1}$ i $P a r_{2}$ ) w paśmie niskich częstotliwości dla danych z: a) próby HCF stali austenitycznej; b) kontroli jakości stopu aluminium (linie przerywane - częstotliwości podręcznego mostka LCR typ UT-612) [4]

Fig. 7. Diagnostic symptoms (estimators $P a r_{1}$ and $P a r_{2}$ ) in the low frequency band for the data of: a) high cycle fatigue of austenitic steel; b) quality control of the aluminum alloy (dashed lines - the measurement frequency of the UT-612 LCR meters) [4]

\section{Wnioski}

Najszersze możliwości funkcjonalne w diagnozowaniu przewodników posiada metoda niskoczęstotliwościowej spektroskopii impedancji, która umożliwia ilościową i jakościową ocenę materiałów ferromagnetycznych, paramagnetycznych i diamagnetycznych, w tym:

- identyfikację parametrów elektrycznych i magnetycznych materiału,

- weryfikację składu chemicznego i mikrostruktury,

- detekcję ukrytych defektów mikrostruktury.

Aplikacją niskoczęstotliwościowej spektroskopii impedancji jest metoda wieloczęstotliwościowych prądów wirowych [23] PMFT, która jest stosowana w przemyśle do kontroli jakości produkcji.

Magnetyczna pamięci metalu i szum Barkhausena są cechami materiału ferromagnetycznego i wzajemnie uzupełniającymi się symptomami diagnostycznymi, wynikającymi w sposób niejawny z charakterystyk częstotliwościowych:

- zespolonej konduktywności elektrycznej,

- zespolonej przenikalności magnetycznej.

Charakterystyki materiałów magnetycznych, wyznaczane w zadanych warunkach otoczenia przy pomocy prądów zmiennych, są w dużej mierze charakterystykami umownymi. W tym przypadku właściwości magnetyczne materiału są ściśle związane ze zjawiskiem prądów wirowych, które są silnie zależne od przewodności właściwej materiału, przenikalności magnetycznej, częstotliwości przemagnesowywania oraz kształtu i wymiarów próbki.

\section{Literatura}

[1] R. Stegemann et al: Metal Magnetic Memory Technique - Prospects and Restrictions, 19th WCNDT, Monachium, 13-17.06.2016.

[2] J. Błachnio: Efekt Barkhausena w diagnostyce elementów maszyn. Biblioteka problemów eksploatacji, Wydawnictwo Naukowe Instytutu Technologii Eksploatacji - PIB, Radom, 2009.

[3] Impedance Measurement Handbook. A guide to measurement technology and techniques. 4th Edition, Keysight Technologies, 2014.
[4] Z. H. Żurek, M. Witoś: Diagnostics of Degradative Changes in Paramagnetic Alloys with the Use of Low Frequency Impedance Spectroscopy, 7th International Symposium on NDT in Aerospace, Bremen, 16-18.11.2015.

[5] M. Roskosz, K. Fryczowski: Porównanie szumu Barkhausena i własnego magnetycznego pola rozproszenia $\mathrm{w}$ odkształconych plastycznie próbkach ze stali S235 i P265GH, Przegląd Spawalnictwa, vol. 84(13), s. $35-40,2012$ 
[6] K. Fryczowski, M. Roskosz, Z. H. Żurek: Badania wstępne wpływu obciążeń rozciągających na parametry obwodu RLC, Przegląd Spawalnictwa, vol. 87(12), s. 45-49, 2015

[7] A. A. Abrikosov: Fundamentals of the Theory of Metals, North-Holland, Amsterdam, Oxford, New York, Tokyo, 1988.

[8] A. A. Shaniavski: Modeling of fatigue cracking of metals. Synergetics for aviation, Publishing House of Scientific and Technical Literature, Monography, Ufa, 2007.

[9] J. Dobrzański: Materiałoznawcza interpretacja trwałości stali dla energetyki, Open Access Library, t. 3, s. 1-228, 2011

[10] F. R. N. Nabarro: Dislocations in a Simple Cubic Lattice, Proc. Phys. Soc. 59(2), s. 256-272, 1947.

[11] V.T. Vlasov, A.A. Dubov: Physical Theory of the Strain - Failure, Process. Part I. Physical Criteria of Metal's Limiting States, Publishing House Spectr, Moscow, 2013.

[12] V.T. Vlasov, A.A. Dubov. Physical Theory of the Strain - Failure, Process. Part II. Process Thermodynamics, Publishing House Spectr, Moscow 2016.

[13] M. Blanter, I. S. Golovin: Internal friction, in: Encyclopedia of Iron, Steel and Their Alloys, Taylor and Francis, New York, s. 1852-1870, 2016.

[14] M. Witoś, M. Zieja, B. Kurzyk: IT Support of NDE and SHM with Application of the Metal Magnetic Memory Method, 7th International Symposium on NDT in Aerospace, Bremen, 16-18.11.2015.

[15] M. Witoś: Increasing the Durability of Turbine Engine Components Through Active Diagnostics and Control, Research works of AFIT, Issue 29, p. 324, 2011.

[16] K. Kashiwaya: Fundamentals of Nondestructive Measurement of Biaxial Stress in Steel Utilizing Magnetoelastic Effect Under Low Magnetic Field, Jpn. J. Appl. Phys., 30, p. 2932, 1991.
[17] M. F. Fischer. Note on the Effect of Repeated Stresses on the Magnetic Properties of Steel, Bureau of Standards Journal of Research, Vol. 1, No. 5, pp. 721-732, 1928.

[18] J. A. Ewing: Magnetic Induction in Iron and Other Metals, The Electrician, Printing and Publishing Co Ltd, London, 1900.

[19] R. R. Birss, C. A. Faunce: Stress-Induced Magnetization in Small Magnetic Fields, Journal de Physique, Colloque $C$ I, supplément au no 2-3, Tome 32 Février-Mars, s. C1686-C1688, 1971.

[20] I. M. Robertson: Magneto-Elastic Behaviour of Steels for Naval Applications, MRL Technical Report MRL-TR-90-27, DSTO Materials Research Laboratory, 1991.

[21] M. Roskosz: Wykorzystanie własnego magnetycznego pola rozproszenia w diagnostyce elementów ferromagnetycznych, Wydawnictwo Politechniki Śląskiej, Gliwice, 2014.

[22] Roskosz M., Fryczowski K., Griner S., Katunin A.: Analiza możliwości oceny procesu pełzania stali $\mathrm{X} 12 \mathrm{CrMoWVNbN10-1-1} \mathrm{na} \mathrm{podstawie} \mathrm{szumu}$ Barkhausena, Przegląd Spawalnictwa, vol. 11, s. 35-40, 2014.

[23] Chady T.: Inspection of Clad Materials Using Massive Multi-Frequency Excitation and Spectrogram Eddy Current Method, 19th WCNDT, Monachium, 13-17.06.2016.

[24] Sikora R.: Elektromagnetyczne Metody Testowania Materii, Instytut Naukowo-Badawczy ZTUREK, 2003.

[25] Mężyk D.: Magnetyczna ocena naprężeń w instalacjach rurociągowych z wykorzystaniem efektu Bar-khausena; Przegląd Spawalnictwa, Vol 86, No 5 (2014). 